\section{Radiocarbon dating and status of the oldest extant Ceylon iron wood (Manilkara hexandra) in the riverine Ramsar site of India}

\author{
Arti Garg ${ }^{1}$, Roxana T. Patrut ${ }^{2, *}$, Adrian Patrut ${ }^{3,4}$, \\ Stephan Woodborne ${ }^{5}$ and Laszlo Rakosy ${ }^{2}$ \\ ${ }^{1}$ Botanical Survey of India, Central Regional Centre, \\ Allahabad 211002 , India \\ ${ }^{2}$ Babeş-Bolyai University, Faculty of Biology and Geology, \\ RO-400015, Cluj-Napoca, Romania \\ ${ }^{3}$ Babeș-Bolyai University, Faculty of Chemistry and Chemical \\ Engineering, RO-400028, Cluj-Napoca, Romania \\ ${ }^{4}$ Babeş-Bolyai University, Raluca Rîpan Institute for Research in \\ Chemistry, RO-400294, Cluj-Napoca, Romania \\ ${ }^{5}$ iThemba LABS, Private Bag 11, WITS 2050, Johannesburg, \\ South Africa
}

\begin{abstract}
During recent field surveys, a new Ceylon iron wood (Manilkara hexandra) population was discovered in the Upper Ganga Ramsar Site, Uttar Pradesh (UP), India. The largest specimen located at Van Khandeshwar partially collapsed in 2012 , which led to a canopy impairment. The rupture enabled direct extraction of samples close to the pith of the main stem. The radiocarbon date of the oldest sample was $361 \pm 23 \mathrm{BP}$, which corresponds to a calibrated age of $525 \pm 25$ cal yr. The results indicate the Ceylon iron wood of Narora, UP is the oldest dated extant $M$. hexandra with a calculated age of $550 \pm 50 \mathrm{yr}$. Several protection measures are presented and urgent action is required to prevent the total collapse of this ancient tree.
\end{abstract}

Keywords: Manilkara hexandra, radiocarbon dating, riverine site, tree conservation.

THE Ceylon iron wood tree, Manilkara hexandra (Roxb.) Dubard of the family Sapotaceae ${ }^{1,2}$, commonly known as khirni in India, is a perennial, evergreen plant with wide usage in Ayurvedic and Unani systems of medicine. It is a stiff tree with shining leathery leaves in densely spreading canopy, adapted to thrive in dry deciduous and evergreen forests. The bark, the highly nutritious fruit berries and the seeds have multiple medicinal uses such as ulorrhagia, ulitis, odontopathy, fever, colic, dyspepsia, heart tonic, revival of consciousness, appetizer, ulcers, opacity of the cornea, etc. ${ }^{3-7}$. The highly prized durable wood which is utilized in making furniture and construction material, also renders important socio-economic value ${ }^{4}$. Some misconceptions pronounced the species as 'Critically Endangered" ${ }^{\prime}$. However, it continues to enjoy the 'Least Concern' status', although it has experienced a drastic decline over the past decades ${ }^{10}$. The global distributional range of $M$. hexandra extends along the South-

\footnotetext{
*For correspondence. (e-mail: roxanapatrut@yahoo.com)
}

east Asian regions of Bangladesh, Cambodia, China, Hainan, India, Malaya, Myanmar, Sri Lanka, Thailand and Vietnam. In India, it is found in Andhra Pradesh, Delhi, Goa, Gujarat, Karnataka, Kerala, Madhya Pradesh, Maharashtra, Rajasthan, Tamil Nadu ${ }^{1-14}$ (Figure 1). However, all these sporadic populations are severely fragmented into subpopulations of 1-25 individuals. Under the Ministry of Environment, Forests and Climate Change, Government of India project on 'Floristic diversity of Upper Ganga Ramsar site in Uttar Pradesh', field surveys were carried out by the Botanical Survey of India during 20122017. The surveyed areas extended from Brij Ghat in Ghaziabad district to Narora in Bulandshahr district of Uttar Pradesh. Here a wild natural population of $M$. hexandra was unearthed in Ram Ghat-Avantika green corridor along the eastern flank of River Ganges from $28^{\circ} 10^{\prime} 38.3^{\prime \prime} \mathrm{N}, 78^{\circ} 12^{\prime} 36.0^{\prime \prime} \mathrm{E}$ at Ram Ghat to $28^{\circ} 26^{\prime} 46.2^{\prime \prime} \mathrm{N}$, $78^{\circ} 14^{\prime} 12.7^{\prime \prime} \mathrm{E}$ at Avantika. Owing to the enormous medicinal and economic attributes ${ }^{15}$, the species is prone to anthropogenic disturbances of high magnitude, already responsible for annihilation of the small interspersed subpopulations, which has created canopy gaps in its wild population girdle at the Upper Ganga Ramsar site. The complete population fragment comprised of 34 mature trees in four subpopulation patches with 4 individuals in Anupshahar, 27 trees in Avantika, 2 in Shikarpura and a single, large tree at Van Khandeshwar in Ram Ghat. This monumental specimen in Ram Ghat is in a dilapidated condition, struggling for survival in its natural abode.

The khirni tree is characterized by its slow growth, requiring about $60-70$ years to attain a moderate height of 5-6 m; consequently, large individuals are potentially very old. Local knowledge and legends suggest that this monumental khirni has survived in its virgin state for several centuries, carving a landmark in the Ramsar landscape.

Dendrochronology in India is a relatively new research direction and most studies have been undertaken to assess the dendrochronological potential of tree species ${ }^{16}$ such as teak (Tectona grandis), oak (Quercus serrata) ${ }^{17}$, toon $(\text { Toona ciliata })^{18}$ and various conifer taxa ${ }^{19}$. Studies on age determination of lofty trees such as Manilkara spp., are scarce as they usually rely on annual ring counts, possible only after the demise of the individuals. However, dendrochronological studies are complex and problematic in tropical trees ${ }^{20}$, which do not necessarily form annual rings and exhibit species-specific phenology and periodicity of cambial activity ${ }^{21,22}$. The underlying causes for the high variability of tree-ring boundaries, which can vary even for the same individual, are not fully understood $^{23}$. Furthermore, a recent study classified $M$. hexan$d r a$ growth rings as indistinct ${ }^{24}$, thus making precise age assessments possible only by modern, alternative methods such as radiocarbon dating ${ }^{25-29}$ or tropical dendrochemistry $^{30}$. To the best of our knowledge, AMS (accelerator mass spectrometry) radiocarbon dating in 


\section{RESEARCH COMMUNICATIONS}

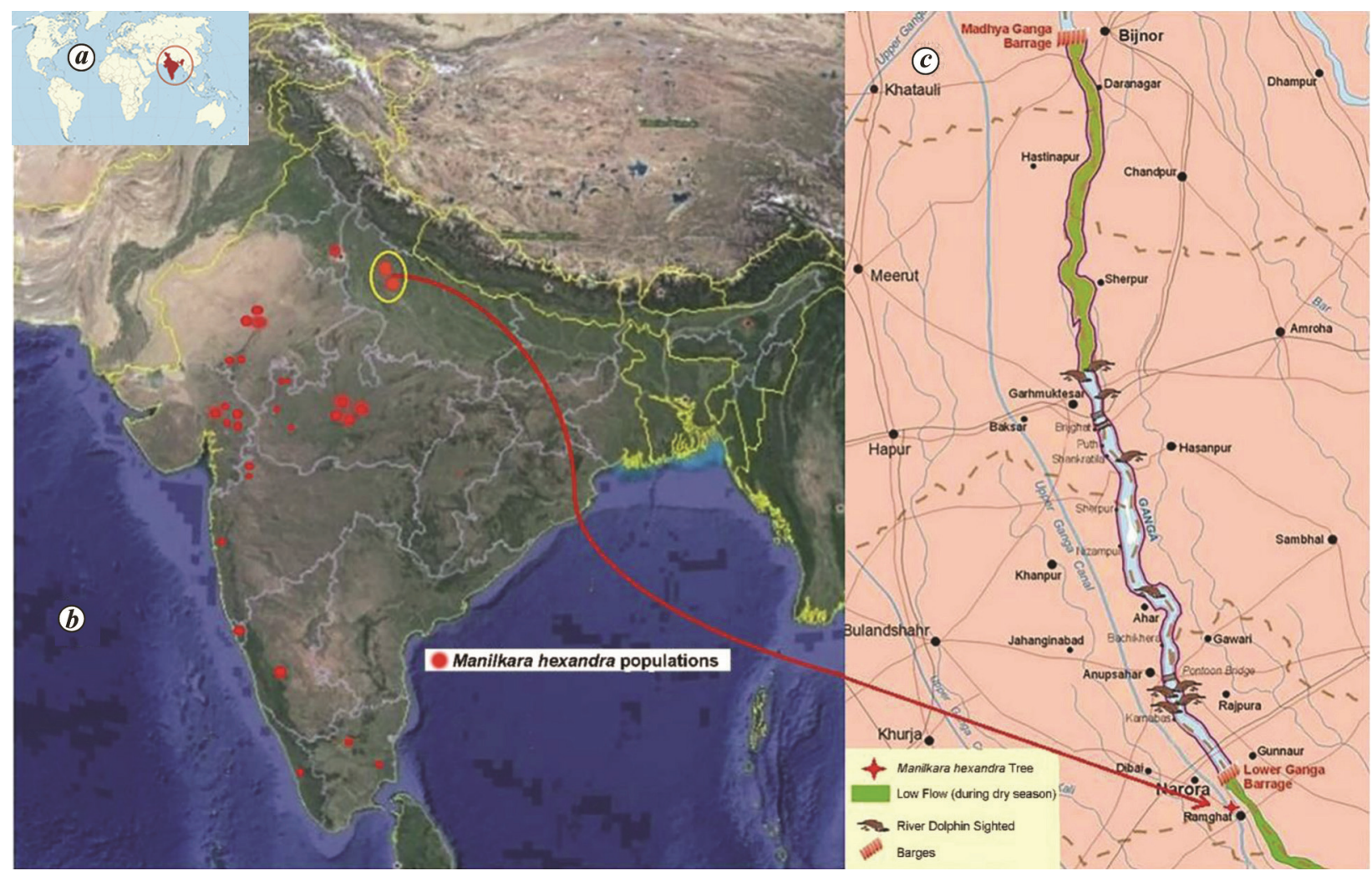

Figure 1. $\boldsymbol{a}$, World map showing the distribution of Manilkara hexandra in Asia. $\boldsymbol{b}$, M. hexandra populations throughout India. $\boldsymbol{c}$, Location of the study khirni marked by a red star. (Source: $(\boldsymbol{a}, \boldsymbol{b})$ Google Earth and (c) World Wildlife Fund.)

India was only performed on African baobab trees (Adansonia digitata). The results revealed the oldest and largest dated specimens outside their native range, namely the baobab of Golconda Fort, Hyderābād (girth of $25.48 \mathrm{~m}$, ca. 475-years-old $)^{29}$, the baobab of Jhunsi, Allahabad and the Parijaat tree at Kintoor (both ca. 800-years-old) ${ }^{31}$.

Old large trees are keystone structures which play crucial roles in providing important services and resources to other species ${ }^{32,33}$. Their existence in a conserved ecosystem such as the Ramsar sites can empower communities by attracting tourists, thus improving local economy. Determining the age limit of the khirni, which has cultural, aesthetical and nutraceutical value, will contribute to better protection and conservation of the species in the context of human development and climate change, and also provide clues to the wild extant gene pool for sustainable utility. AMS radiocarbon dating of the presumed oldest $M$. hexandra tree was therefore performed in order to ascertain the age, disseminate information on its heritage, ensure conservation of the wild gene pool as well as to popularize the specimen.

The very large $M$. hexandra is located within the Upper Ganga Ramsar site at Van Khandeshwar, Narora area, Uttar Pradesh, India. It is positioned about $8 \mathrm{~km}$ from the Narora Atomic Power Station on the northeastern flank of River Ganga at $28^{\circ} 08.630^{\prime} \mathrm{N}, 078^{\circ} 26.229^{\prime} \mathrm{E}$, at an altitude of $169 \mathrm{~m}$ amsl (Figure 1). The mean annual rainfall recorded at Narora station is $902 \mathrm{~mm}$. The khirni is surrounded by a $0.60 \mathrm{~m}$ tall platform, erected as a protection structure, which highlights its importance among the community. In 2012, a large quadri-branched unit rippedoff almost halfway from the main bole, leaving behind a gaping lesion with open heartwood and inner tissues (Figure $2 a$ ). Wood from the fallen unit was slowly cutoff and used by locals, while the lesion was subject to further infection and decay (Figure $2 b$ ). Due to cutting of wood from the fallen unit, the annual rings could be counted. The largest branch had 296 distinct annual rings in 2012, which indicated the present age of this branch to be more than 300 years old and the age of the tree to be much older around 500 years. At present, the tree consists of 2-3 stems and seven main basal primary branches. The current height of the tree is $14.9 \mathrm{~m}$ and circumference at breast height (cbh; at $1.30 \mathrm{~m}$ above ground) is $4.83 \mathrm{~m}$. The restored cbh (including the fallen branch) is $6.13 \mathrm{~m}$.

The wood of $M$. hexandra is very hard and dense ${ }^{8}$, which renders it almost impossible to sample by an increment borer. The fallen unit exposed the heartwood of the main stem and enabled direct access to the oldest part of the specimen, which was identified after careful visual inspection. Following the methodology of Patrut et $a l .^{27-29,31,34}$ for radiocarbon dating of standing, live trees, three samples were extracted with a sharp object close to the presumptive pith of the oldest stem. The sampling 


\section{RESEARCH COMMUNICATIONS}

Table 1. AMS radiocarbon dating results and calibrated calendar ages of samples collected from Manilkara hexandra at Van Khandeshwar, Uttar Pradesh, India

\begin{tabular}{|c|c|c|c|c|c|c|}
\hline $\begin{array}{l}\text { Sample/ } \\
\text { segment }\end{array}$ & $\begin{array}{c}\text { Fraction modern } \\
\text { [error] }\end{array}$ & $\begin{array}{l}\text { Radiocarbon date } \\
\text { [error] }\left({ }^{14} \mathrm{C} \text { yr BP }\right)\end{array}$ & $\begin{array}{l}\text { Isotopic fractiona- } \\
\text { tion } \delta^{13} \mathrm{C}(\%)\end{array}$ & $\begin{array}{c}\text { Cal CE range } 1 \sigma \\
\text { [confidence interval] }\end{array}$ & $\begin{array}{c}\text { Sample age in } 2020 \\
\text { [error] (cal yr) }\end{array}$ & Accession \# \\
\hline MH-1 & $0.9587[ \pm 0.0026]$ & $338[ \pm 21]$ & -26.9 & $\begin{array}{c}1494-1524[21.7 \%] \\
\mathbf{1 5 5 8}-\mathbf{1 6 0 2}[\mathbf{3 3 . 9 \%}] \\
1615-1631[12.6 \%]\end{array}$ & $440[ \pm 20]$ & IT-C-2692 \\
\hline MH-2 & $0.9560[ \pm 0.0029]$ & $361[ \pm 23]$ & -26.6 & $\begin{array}{l}\mathbf{1 4 6 6}-1521[44.3 \%] \\
1591-1620[23.9 \%]\end{array}$ & $525[ \pm 25]$ & IT-C-2702 \\
\hline MH-3 & $1.0709[ \pm 0.0032]$ & - & -27.3 & $2003-2005[68.2 \%]$ & $16[ \pm 1]$ & IT-C-2700 \\
\hline
\end{tabular}

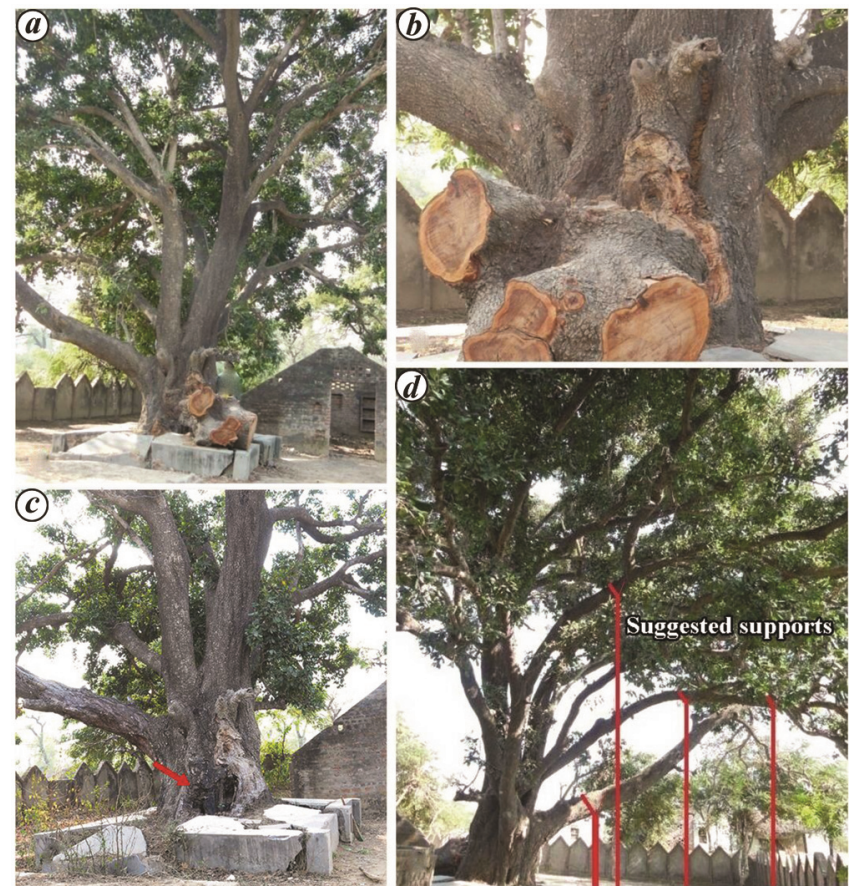

Figure 2. $\boldsymbol{a}$, The monumental khirni at Van Khandeshwar, Uttar Pradesh, India after partial collapse in 2012. $\boldsymbol{b}$, Ring count of the largest fallen unit yielded 296 years. $c$, The scorched part of the trunk is shown; the charred wood of the lesion is indicated with a red arrow. $d$, Suggested supports for the remaining branches are an urgent requirement for survival of the tree.

height varied between 1.00 and $1.38 \mathrm{~m}$. A tiny piece (segment) of wood was selected from each sample for AMS radiocarbon dating. The segments were labelled as MH-1, MH-2 and MH-3.

Pretreatment of wood samples is necessary prior to radiocarbon dating in order to isolate the cellulose from the non-structural mobile carbon components, such as lignin. The $\alpha$-cellulose pretreatment method modified by Loader et $a l .{ }^{35}$ was used on the sample segments. The obtained cellulose was further combusted to $\mathrm{CO}_{2}$ and subsequently reduced to graphite on iron catalys $\mathrm{t}^{36,37}$. The resulting graphite samples were analysed by AMS.

AMS radiocarbon measurements were performed at the AMS Facility of iThemba LABS (Laboratory for Accelerator-Based Sciences) in Johannesburg, South Africa, with the $6 \mathrm{MV}$ Tandem AMS system ${ }^{38}$. The resulting fraction modern values, which were corrected for isotopic fractionation, were ultimately converted to radiocarbon dates. The radiocarbon dates and corresponding errors were rounded to the nearest year.

The OxCal v4.3 for Windows ${ }^{39}$ and the IntCal13 atmospheric dataset ${ }^{40}$ were selected for calibrating and converting radiocarbon dates into calendar ages. For sample MH-3, the fraction modern value corresponds to a negative radiocarbon date, demonstrating that the ${ }^{14} \mathrm{C}$ activity has a higher value than the standard activity registered in the reference year 1950 (Table 1). Thus, the Bomb 13 NH3 atmospheric dataset ${ }^{41}$ was selected for calibrating the fraction modern value of this sample segment. The calibration program and datasets are available online with updates (accessible at: www.c14.arch.ox. ac.uk).

Table 1 presents the radiocarbon dating results and calibrated ages. Radiocarbon dates and errors, which are expressed in ${ }^{14} \mathrm{C}$ yr BP (radiocarbon years before present, i.e. before the reference year $1950 \mathrm{CE}$ ), were rounded to the nearest year. Calibrated ages and age ranges are expressed in calendar years.

The $1 \sigma$ probability distribution $(68.2 \%$ confidence interval) was selected to derive calibrated age ranges. For $\mathrm{MH}-3$, the $1 \sigma$ probability distribution was consistent with one range of calendar years. For $\mathrm{MH}-1$ and $\mathrm{MH}-2$, the $1 \sigma$ probability distribution was consistent with three or two ranges of calendar years respectively. In these cases, the age range with the highest confidence interval has been marked in bold in Table 1, and selected as the calibrated $\mathrm{CE}$ (cal CE) range of the sample for the purpose of discussion. For obtaining single calendar age values, the mean value of the selected age range was calculated. The sample ages represent the difference between the year 2020 and the mean value of the selected range, with the corresponding error. Sample ages and the corresponding errors were rounded to the nearest 5 years.

The radiocarbon date of $\mathrm{MH}-1$ is $338 \pm 21 \mathrm{BP}$ and corresponds to a calibrated age of $440 \pm 20 \mathrm{cal} \mathrm{yr}$, which represents a very old Ceylon iron wood. For the second sample $\mathrm{MH}-2$, the radiocarbon date of $361 \pm 23 \mathrm{BP}$ corresponds to a calibrated age of $525 \pm 25 \mathrm{cal}$ yr. This is the oldest dating result for a khirni, be it by traditional dendrochronological techniques or radiocarbon investigations. 
Due to the hardness of the wood, MH-2 was extracted close to the presumptive pith, where the morphology of the lesion allowed easy access and extraction. Thus, the calculated age of the studied stem is $550 \pm 50 \mathrm{yr}$. From this value, the khirni at Van Khandeshwar becomes the oldest extant $M$. hexandra specimen with accurate dating results. The results complement well with the local knowledge and our previous ring count.

For sample MH-3, the results correspond to a negative radiocarbon date, which implies the wood tissue was formed after the reference year $1950 \mathrm{CE}$ (0 BP). The calibration process provided a calibrated age of $16 \pm 1 \mathrm{yr}$. This result reflects a troubled history, indicating tissue damage probably caused by fire or lightning about 16 years ago. The locals usually pay tribute to the tree, sitting on the platform or performing rituals, which involves smoke and fire. Furthermore, according to the local informers, controlled burning of termite-infected wood was undertaken in the past to prevent further infection in the khirni (Figure $2 c$ ). Another explanation for such a young age would be the presence of regrowth tissue over an infected area. However, only a detailed anatomical study could confirm the same. Whatever be the cause, the injury must have contributed to the rupture of the quadribranched unit 8 years ago and the loss of almost half of the crown (Figure 2). The rupture exposed the wood tissue to further pathogen attacks and displaced the gravitational centre disproportionately to one side.

The $14 \mathrm{~m}$ tall khirni tree at Van Khandeshwar is currently in a precarious condition due to old age and an asymmetrical canopy structure, which has reduced its capacity to withstand physical, anthropogenic and climatic pressures. Under continuous growth and increasing foliage, a total collapse of the tree is inevitable. Very old trees exhibit high phenotypic plasticity, carrying a complete set of resistant, feral genetic constituents, which have invaluable application for generating improved disease-resistant cultivars. Concerted efforts for conservation of this ancient tree are urgently recommended before causing irreparable damage to the biodiversity of this eco-sensitive, fragile and biologically susceptible, exclusive riverine ecosystem and Ramsar site of India. An immediately possible protective measure is to furnish solid, forked, logs or pole supports (Figure $2 d$ ) to the spreading branches to counteract the disproportionate gravitational pull on the tree. Fencing is also necessary to deter children from climbing up on the brittle branches as hideouts. The exposed heartwood and inner tissues at the ruptured part of main trunk need to be carefully sealed to avert biological infection and mechanical injury. Artificial propagation is also necessary as the aged tree has not bloomed for about 15 years and lacks natural reproduction. The need for increasing tree numbers in natural habitats through large-scale plantations to bridge the green corridor gaps and join subpopulation fragments is also indicated. Raising awareness on the high nutraceuti- cal value of the specimen can encourage its inclusion in reforestation efforts on local or larger scale, to be used as accessible medicine. These measures will augment pollination in this bee-pollinated species ${ }^{42}$ by attracting viable pollinators to increased number of flowers as well as in harnessing its potential fruit yield. Any possible hormonal treatment to stimulate branching on the vacant left side of the trunk would be a boon for the survival of the oldest dated Ceylon iron wood tree.

The khirni at Van Kandeshwar has survived for at least 500 years, while withstanding various biotic and abiotic factors, including extreme weather events, thus becoming a good candidate for genome sequencing, in order to be preserved and planted for the future, especially in the context of climate change. Multiplication and production of genetic replicas through tissue culture techniques are required for conservation of the original gene pool.

The newly discovered population of khirni consists of wild and exceptional specimens. This study was undertaken in order to ascertain the upper age limit of the species to allow for conservation strategies and popularization. The oldest sample has a radiocarbon age of $361 \pm 23 \mathrm{BP}$, which corresponds to a calibrated age of $525 \pm 25 \mathrm{cal} \mathrm{yr}$. The calculated age of $550 \pm 50 \mathrm{yr}$, demonstrates the Ceylon iron wood at Van Khandeshwar is the oldest extant $M$. hexandra, a parent ancestor of the existing populations, manifesting important archaic botanical treasure. A large unit split-off and died, causing unbalanced canopy structure. The age assessment indicates a 16-years old injury contributed to the partial collapse. Integrated measures and judicious actions are essential for immediate salvage and sustenance of the oldest, but perilous, exclusive tree floral component of the only riverine Upper Ganga Ramsar site of India.

Ethical statement. The study and sampling of the khirni was approved and supported by the Botanical Survey of India, Central Regional Centre of Allahabad and authorized by the National Biodiversity Authority of India (NBA/9/2269/18/18-19).

1. Dubard, P. M. M., Manilkara hexandra (Roxb.) Dubard. Ann. Mus. Colon. Marseille, 1915, 3, 9.

2. Roxburgh, M. D. W., Plants of the Coast of Coromandel, Vol. 1, W. Bulmer and Co., Shakespeare Printing Office, London, 1795, p. 15; https://www.biodiversitylibrary.org/item/9711\#page/1/mode/ lup

3. Shah, M. B., Goswami, S. S. and Santani, D. D., Effect of Manilkara hexandra (Roxb.) Dubard against experimentally-induced gastric ulcers. Phytother. Res., 2004, 18, 814-818.

4. Malik, S. K., Choudhary, R., Kumar, S., Dhariwal, O. P., Deswal, R. P. S. and Chaudhury, R., Socio-economic and horticultural potential of khirni [Manilkara hexandra (Roxb.) Dubard]: a promising underutilized fruit species of India. Genet. Resour. Crop. Evol., 2012, 59, 1255-1265.

5. Mishra, N. and Pareek, A., Traditional uses, phytochemisty and pharmacology of Mimusops hexandra Roxb. Adv. Pharm. Ethnomed., 2014, 2, 32-35. 
6. Pingili, D., Awasthi, A. and Amminbavi, D., Assessment of in vitro antiarthritic activity of Manilkara hexandra (Roxb.) Dubard leaf extract. Ann. Phytomed., 2016, 5, 152-155.

7. Anjali, Garg, V., Dhiman, A., Dutt, R. and Ranga, S., The genus Manilkara: an update. Pharma Innov., 2018, 7, 316-318.

8. Keerthika, A., Shukla, A. K. and Khandelwal, V., Popularization of Manilkara hexandra (khirni) - an endangered underutilized fruit tree for conservation and utilization. Curr. Sci., 2015, 109, 1010-1011.

9. IUCN, The IUCN Red List of Threatened Species. Version 2019-3, 2019; http://www.iucnredlist.org (accessed on 10 December 2019).

10. Gunarathne, U. K. and Perera, A., Is Manilkara hexandra (Roxb.) Dubard, a threatened species in Sri Lanka? In Proceedings of the 29th Annual Sessions of the Institute of Biology, Colombo, Sri Lanka, 2009.

11. Shetty, B. V. and Singh, V., Flora of Rajasthan, Series 2, Botanical Survey of India, Dehradun, 1991, p. 460.

12. Mudgal, V., Khanna, K. K. and Hajra, P. K., Flora of Madhya Pradesh, Series 2, Botanical Survey of India, Calcutta, 1997, p. 14.

13. Krishen, P., Trees of Delhi: A Field Guide, Dorling Kindersley Pvt Ltd, India, 2006, p. 139

14. Nayar, T. S., Beegam, A. P. and Sibi, M., The Western Ghats, Vol. 1, Jawaharlal Nehru Tropical Botanic Garden and Research Institute, Thiruvananthapuram, 2014, p. 835.

15. Pareek, O. P., Sharma, S. and Arora, R. K., Underutilized edible fruits and nuts: an inventory of genetic resources in their regions of diversity. International Plant Genetic Resources Institute, New Delhi, 1998, p. 73.

16. Suresh, H. S., Do trees tell us about the past? Resonance, 2012, 17, 33-43.

17. Upadhyay, K. K., Shah, S. K., Roy, A., Mehrotra, N. and Tripathi, S. K., Dendrochronological potential of Tectona grandis, Pinus kesiya and Quercus serrata from Mizoram, northeast India. Indian J. Ecol., 2019, 46, 722-728.

18. Shah, S. K. and Mehrotra, N., Tree-ring studies of Toona ciliata from subtropical wet hill forests of Kalimpong, eastern Himalaya. Dendrochronologia, 2017, 46, 46-55.

19. Pandey, U., Shah, S. K. and Mehrotra, N., Tree-ring studies from Kashmir Valley: present status and future perspective. Geophyto$\log y, 2016,46,207-220$.

20. Patrut, A. et al., The growth stop phenomenon of baobabs (Adansonia spp.) indentified by radiocarbon dating. Radiocarbon, 2017 , 59, 435-448.

21. Bormann, F. H. and Berlyn, G., Age and growth rate of tropical tees: new directions for research. School of Forestry and Environmental Studies Bulletin, Yale University, USA, 1981.

22. Pumijumnong, N., Dendrochronology in Southeast Asia. Trees, 2013, 27, 343-358.

23. Tarelkin, Y., Delvaux, C., De Ridder, M., El Berkani, T., De Cannière, C. and Beeckman, H., Growth-ring distinctness and boundary anatomy in tropical trees. IAWA J., 2016, 37, 275-294; doi:10.1163/22941932-20160134.

24. Baguinon, N. T., Borgaonkar, H., Gunatilleke, N., Duangsathaporn, K., Buckley, B. M., Wright, W. E. and Maid, M., Collaborative Studies in Tropical Asian Dendrochronology: Addressing Challenges in Climatology and Forest Ecology. Final report for APN project: ARCP2008-03CMY-Baguinon, Asia-Pacific Network for Global Change Research, 2009.

25. Worbes, M., One hundred years of tree-ring research in the tropics - a brief history and an outlook to future challenges. Dendrochronologia, 2002, 20, 217-231.

26. Fichtler, E., Clark, D. A. and Worbes, M., Age and long-term growth of trees in an old-growth tropical rain forest, based on analyses of tree rings and ${ }^{14}$ C. Biotropica, 2003, 35, 306-317.

27. Patrut, A., von Reden, K. F., Danthu, P., Leong Pock-Tsy, J.-M., Patrut, R. T. and Lowy, D. A., Searching for the oldest baobab of
Madagascar: radiocarbon investigation of large Adansonia rubrostipa trees. PLoS ONE, 2015, 10, e0121170.

28. Patrut, A., Woodborne, S., Patrut, R. T., Rakosy, L., Lowy, D. A., Hall, G. and von Reden, K. F., The demise of the largest and oldest African baobabs. Nature Plants, 2018, 4, 423-436.

29. Patrut, A., Garg, A., Woodborne, S., Patrut, R. T., Rakosy, L., Ratiu, I. A. and Lowy, D. A., Radiocarbon dating of two old African baobabs from India. PLoS ONE, 2020, 15, e0227352.

30. Poussart, P. M., Myneni, S. C. B. and Lanzirotti, A., Tropical dendrochemistry: a novel approach to estimate age and growth from ringless trees. Geoophys. Res. Lett., 2006, 33, L17711.

31. Patrut, A., Patrut, R. T., Rakosy, L., Bodis, J., Lowy, D., Forizs, E. and von Reden, K. F., African baobabs with double closed ringshaped structures and two separate false cavities: radiocarbon investigation of the baobab of Golconda Fort. Stud. Univ. BabesBolyai Chemia, 2016, LXI, 21-30.

32. Lindenmayer, D. B., Laurence, W. F. and Franklin, J. F., Global decline in large old trees. Science, 2012, 338, 1305-1306.

33. Stagoll, K., Lindenmayer, D. B., Knight, E., Fischer, J. and Manning, A. D., Large trees are keystone structures in urban parks. Conserv. Lett., 2012, 5, 115-122.

34. Patrut, A. et al., Fire history of a giant African baobab evinced by radiocarbon dating. Radiocarbon, 2010, 52, 717-726.

35. Loader, N. J., Robertson, I., Barker, A. C., Switsur, V. R. and Waterhouse, J. S., An improved technique for the batch processing of small wholewood samples to $\alpha$-cellulose. Chem. Geol., 1997, 136, 313-317.

36. Sofer, Z., Preparation of carbon dioxide for stable carbon isotope analysis of petroleum fractions. Anal. Chem., 1980, 52, 13891391.

37. Vogel, J. S., Southon, J. R., Nelson, D. E. and Brown, T. A., Performance of catalytically condensed carbon for use in accelerator mass-spectrometry. Nucl. Instrm. Methods B., 1984, 5, 289-293.

38. Mbele, V. L., Mullins, S. M., Winkler, S. R. and Woodborne, S., Acceptance tests for AMS radiocarbon measurements at iThemba LABS, Gauteng, South Africa. Phys. Procedia, 2017, 90, 10-16.

39. Bronk Ramsey, C., Bayesian analysis of radiocarbon dates. Radiocarbon, 2009, 51, 337-360.

40. Reimer, P. J. et al., J., IntCal13 and Marine13 radiocarbon age calibration curves, 0-50,000 years cal BP. Radiocarbon, 2013, 55, 1869-1887.

41. Hua, Q., Barbetti, M. and Rakowski, A. J., Atmospheric radiocarbon for the period 1950-2010. Radiocarbon, 2013, 55, 20592072 .

42. Attar, S. K., Thakur, N. S., Patel, H. F., Singh, N. D., Makawana, A. I., Leua, H. N. and Parmar, S. G., Underutilized fruit Manilkara hexandra (khirni). Rashtriya Krishi, 2016, 11, 17-18.

ACKNOWLEDGEMENTS. This research was funded by the Romanian Ministry of National Education CNCS-UEFISCDI under grant PNIII-P4-ID-PCE-2016-0776, No. 90/2017. We thank the Director, Botanical Survey of India (BSI), Kolkata and the Head, Central Regional Centre of BSI, Allahabad, for encouragement and providing the necessary facilities.

Received 9 March 2020; revised accepted 18 November 2020

doi: $10.18520 / \mathrm{cs} / \mathrm{v} 120 / \mathrm{i} 3 / 562-566$ 